\title{
Aktivitas Fisik, Stres, dan Obesitas pada Pegawai Negeri Sipil
}

\author{
Physical Activity, Stress and Obesity among Civil Servant
}

\author{
Winne Widiantini* Zarfiel Tafal**
}

\author{
*Pusat Data dan Informasi Sekretariat Jenderal Kementerian Kesehatan Republik Indonesia, **Departemen \\ Pendidikan Kesehatan dan Ilmu Perilaku Fakultas Kesehatan Masyarakat Universitas Indonesia
}

\begin{abstract}
Abstrak
Pada tahun 2008, sekitar 2,8 juta orang dewasa meninggal akibat obesitas, sekitar 300 juta orang yang secara klinis tergolong obesitas yang merupakan penyokong utama penyakit degeneratif seperti diabetes, penyakit jantung, dan kanker. Penelitian ini bertujuan mengetahui prevalensi obesitas pada Pegawai Negeri Sipil (PNS) Sekretariat Jenderal Kementerian Kesehatan Republik Indonesia dan pengaruh aktivitas fisik dan stres terhadap obesitas. Penelitian potong lintang ini dilakukan pada bulan Mei Juni 2013 di Jakarta pada 230 responden yang dipilih secara acak sistematik dari 1.119 PNS. Obesitas diukur dengan Indeks Massa Tubuh (IMT) berupa rasio berat badan (kilogram) dibagi tinggi badan kuadrat (meter ${ }^{2}$ ), responden dinyatakan obesitas jika IMT $\geq 25 \mathrm{~kg} / \mathrm{m}^{2}$. Prevalensi obesitas pada PNS Sekretariat Jenderal Kementerian Kesehatan RI Tahun 2013 adalah 48\%. Setelah dikontrol oleh konsumsi makanan dan usia didapatkan hubungan yang signifikan antara aktivitas fisik dan stres dengan obesitas. Kelompok yang melakukan aktivitas fisik sedang atau berat berisiko 0,4 atau 0,6 kali lebih rendah untuk mengalami obesitas dan kelompok yang mengalami stres sedang atau berat berisiko 4,6 atau 2,4 kali lebih besar untuk mengalami obesitas. Disarankan Kementerian Kesehatan melakukan pemeriksaan obesitas pada semua pegawai secara rutin dan menyelenggarakan olahraga rutin setiap hari serta memanfaatkan fasilitas olahraga (fitness center) untuk menjaga kebugaran.

Kata kunci: Aktivitas fisik, obesitas, stres
\end{abstract}

\section{Abstract}

In 2008, about 2,8 milion adult people were dead caused by obesity, about 300 milions people who clinically obese who is main support of degenerative diseases such as diabetes mellitus, heart desease, and cancer. This study aimed to know the prevalence of obesity among civil servant Secretariat General of the Ministry of Health of Republic of Indonesia and the effect of physical activity and stress. The cross sectional studies was performed on 230 respondents who selected by systematic random sam- pling. Obesity is measured using Body Mass Index (BMI) i.e. the ratio between the weight (in kilograms) divided by height (in meters squares), obesity exist if $\mathrm{BMI} \geq 25 \mathrm{~kg} / \mathrm{m}^{2}$. Data analysis was done using multivariate logistic regression. Results of the study showed that the prevalence of obesity is $48 \%$. After controlled by nutrient intake and age there is a significant relationship between physical activity and stress with obesity. Moderate and heavy physical activity have a risk of 0.4 or 0.6 times less likely to be obese and groups who experience moderate or severe stress has a risk of 4.6 or 2.4 times more likely to be obese. Advised on the Ministry of Health to conduct regular monitoring of the occurrence of obesity in all its employees and create aschedule and applying the best workouts together and makeuse of the sports facilities (fitness center).

Keywords: Physical activity, obesity, stress

\section{Pendahuluan}

Pada tahun 2008, sekitar 2,8 juta orang dewasa meninggal akibat obesitas, sekitar 300 juta orang yang secara klinis tergolong obesitas yang merupakan penyokong utama dari penyakit degeneratif seperti diabetes, penyakit jantung dan kanker. Obesitas merupakan kondisi pertambahan lemak tubuh yang didasarkan pada nilai indeks massa tubuh (IMT). ${ }^{1}$ Asupan makanan berlebih disimpan sebagai cadangan energi dalam bentuk lemak yang dalam jangka panjang mengakibatkan cadangan lemak ditimbun semakin banyak dalam tubuh yang menyebabkan obesitas, kondisi abnormal kelebihan lemak yang serius dalam jaringan adiposa yang mengganggu kesehatan. Obesitas secara klinis dinyatakan

Alamat Korespondensi: Winne Widiantini, Pusat Data dan Informasi Sekjen Kementerian Kesehatan RI, Jl. H.R. Rasuna Said Kav. X-5 No. 4-9 Jakarta Selatan, Hp.081381339695, e-mail: bunda.inne@yahoo.com 
dalam bentuk IMT $\geq 25 \mathrm{~kg} / \mathrm{m}^{2}$, kegemukan dan obesitas merupakan faktor risiko kejadian penyakit degeneratif seperti diabetes melitus tipe 2, hipertensi, kardiovaskular, dan kanker. ${ }^{2-3}$ Obesitas menyebabkan sekitar $44 \%$ penyakit diabetes, $23 \%$ penyakit jantung, dan $41 \%$ penyakit kanker. ${ }^{4}$

Menurut World Health Organization (WHO), pada tahun 2011, satu dari sepuluh orang dewasa mengalami obesitas. ${ }^{2}$ Di kawasan Asia-Pasifik, prevalensi obesitas meningkat sangat tajam, sekitar 20,5\% penduduk Korea Selatan tergolong overweight dan 1,5\% tergolong obesitas. Di Thailand, $16 \%$ tergolong overweight dan $4 \%$ tergolong obesitas. Di semua wilayah di Asia Tenggara, perempuan lebih banyak menderita obesitas dibanding pria. ${ }^{2}$ Berdasarkan data National Health and Nutrition Examination Survey (NHANES), pada orang dewasa usia 20 - 74 tahun, di Amerika Serikat pada tahun 1960 - 2008, terjadi peningkatan obesitas hingga 34,3\%. ${ }^{5} \mathrm{Di}$ Indonesia, obesitas merupakan salah satu permasalahan gizi, berdasarkan hasil Riset Kesehatan Dasar tahun 2007, prevalensi obesitas pada penduduk dewasa usia diatas 18 tahun adalah sebesar $11,7 \%$. Prevalensi obesitas berbeda menurut jenis kelamin, pada laki-laki adalah $7,8 \%$ dan pada perempuan adalah $15,5 \% .^{6}$

Berbagai faktor yang meningkatkan risiko obesitas yang meliputi jenis kelamin, usia, pengetahuan gizi, pendidikan terakhir, sikap tentang obesitas, konsumsi zat gizi yang meliputi konsumsi energi, karbohidrat, lemak, dan protein, aktivitas fisik, dan stres. Pertambahan usia membuat aktivitas bergerak menjadi berkurang sehingga massa otot dalam tubuh menurun. Kehilangan massa otot menyebabkan perlambatan tingkat pembakaran kalori, tanpa mengurangi jumlah asupan kalori terjadi penumpukan energi di dalam tubuh yang pada akhirnya mengakibatkan obesitas. ${ }^{7}$ Pola makan merupakan salah satu kunci utama agar terhindar dari penyakit tidak menular seperti penyakit jantung koroner, kanker, dan diabetes. WHO merekomendasikan peningkatan konsumsi buah dan sayur serta pembatasan asupan lemak jenuh, gula sederhana, dan natrium. Ada hubungan yang bermakna antara pola makan dengan kejadian obesitas. ${ }^{8}$ Aktivitas fisik adalah pergerakan tubuh yang dihasilkan oleh otot rangka yang mengeluarkan energi. Aktivitas fisik yang cukup pada orang dewasa dapat menurunkan risiko hipertensi, penyakit jantung koroner, stroke, diabetes, dan kanker. ${ }^{2}$ Berbagai penelitian menyimpulkan hubungan yang bermakna antara aktivitas fisik dengan kejadian obesitas, risiko obesitas semakin rendah dengan aktivitas fisik yang tinggi. ${ }^{9-12}$

Kementerian Kesehatan Republik Indonesia (Kemenkes RI) bertugas membantu Presiden menyelenggarakan urusan pemerintahan di bidang kesehatan. Pegawai Kemenkes RI dianjurkan melakukan pemeriksaan kesehatan ke beberapa rumah sakit rujukan, tetapi penelitian tentang obesitas belum pernah dilakukan. Penelitian ini bertujuan mengetahui kejadian obesitas pada Pegawai Negeri Sipil (PNS) Sekretariat Jenderal Kementerian Kesehatan RI, tahun 2013 dan hubungan dengan aktivitas fisik dan stres.

\section{Metode}

Penelitian ini menggunakan desain survei potong lintang (cross sectional), pengukuran variabel dependen obesitas dan variabel independen aktivitas fisik dan stres dilakukan pada waktu bersamaan pada bulan Mei - Juni 2013. Populasi pada penelitian ini adalah seluruh PNS Sekretariat Jenderal Kementerian Kesehatan Republik Indonesia yang berstatus PNS sebanyak 1.119 pegawai. Kriteria inklusi adalah pegawai yang telah menjadi PNS minimal selama dua tahun dan kriteria eksklusi adalah pegawai yang mempunyai masalah fisik berupa sakit atau cacat serta pegawai yang sedang hamil. Besar sampel ditentukan berdasarkan rumus pengujian hipotesis beda dua proporsi, kejadian obesitas pada kelompok berpengetahuan kurang sebesar $43,4 \%$ dan pada berpengetahuan baik sebesar 19,6\%, menggunakan derajat kemaknaan 5\% dan kekuatan uji 95\%, maka sampel minimum yang dibutuhkan adalah 210 responden. Sampel terpilih pada penelitian ini adalah 230 pegawai yang dipilih secara acak sistematis.

Pengumpulan data, pengukuran status gizi, pengukuran asupan zat gizi, dan wawancara tentang aktivitas fisik dilakukan oleh dua orang lulusan sarjana gizi yang sudah dilatih. Ukuran yang digunakan untuk menentukan seseorang menderita obesitas adalah berdasarkan berat badan dan tinggi badan dengan menggunakan IMT yang dihitung berdasar berat badan dalam kilogram dibagi tinggi badan dalam $\mathrm{m}^{2}$. Penilaian status gizi dilakukan secara langsung menggunakan antropometri yang secara umum untuk melihat keseimbangan asupan protein dan energi. Pengukuran IMT merupakan cara sederhana yang cepat dan mudah untuk memantau status gizi orang dewasa usia 18 tahun atau lebih. Cut off point IMT untuk orang Indonesia dimodifikasi oleh Kementerian Kesehatan RI berdasarkan pengalaman klinis dan hasil penelitian di beberapa negara berkembang. Kategori IMT untuk Indonesia adalah kurus (IMT< $<18,5$ ); normal (IMT 18,5 - 25,0); gemuk atau kelebihan berat badan atau obesitas $(>25,0) .{ }^{6}$ Pengukuran berat badan dilakukan dengan timbangan digital dengan ketelitian 0,1 kilogram dan pengukuran tinggi badan menggunakan meteran dengan ketelitian 0,1 centimeter.

Pengukuran aktivitas fisik sehari-hari yang dilakukan oleh responden menggunakan kuesioner Baecke dan pengukuran stres dengan pengisian kuesioner Personal Stress Inventory. Pengukuran asupan zat gizi (konsumsi energi, karbohidrat, lemak, dan protein) menggunakan recall 24 hours, responden ditanyakan asupan makanan 
selama satu hari ke belakang beserta ukurannya. Data wawancara asupan zat gizi kemudian diolah menggunakan perangkat lunak. Berdasarkan rekomendasi Departemen Kesehatan Republik Indonesia pengelompokan konsumsi energi dibagi menjadi dua, yaitu $\leq 60 \%$ angka kecukupan gizi (AKG) dikatakan kurang dan $>60 \%$ AKG dikatakan cukup. Analisis data untuk mengetahui pengaruh aktivitas fisik dan stres terhadap obesitas setelah dikontrol oleh karakteristik responden dan asupan gizi dilakukan dengan regresi logistik multivariat.

\section{Hasil}

Pada tahun 2013, hampir separuh PNS Sekretariat Jenderal Kementerian Kesehatan RI mengalami kelebihan berat badan atau obesitas $(48,3 \%)$. Sebagian besar tamat perguruan tinggi $(74,8 \%)$ dan berpengetahuan kurang tentang gizi dan obesitas $(77,8 \%)$. Responden yang mempunyai sikap positif terhadap obesitas hampir sama dengan yang mempunyai sikap negatif.

Sebagian besar responden biasa melakukan aktivitas fisik ringan $(33,9 \%)$, sisanya biasa melakukan aktivitas fisik sedang $(36,5 \%)$, dan sekitar $29,6 \%$ melakukan aktivitas fisik berat. Sebagian besar mengalami stres berat $(60 \%)$, sisanya mengalami stres sedang $(33,5 \%)$, dan stres ringan sebesar 6,5\% (Tabel 1). Sebagian besar $(74,3 \%)$ mempunyai konsumsi energi kurang dari AKG dan yang konsumsi kurang karbohidrat adalah sekitar $74,8 \%$, konsumsi kurang lemak sekitar 75,2\%, dan konsumsi kurang protein sekitar $77,8 \%$.

Dengan uji regresi logistik sederhana, terlihat bahwa dari 11 variabel independen hanya tiga yang berhubungan bermakna dengan obesitas, meliputi aktivitas fisik, tingkat stres, dan usia. Kejadian obesitas lebih rendah jika responden mempunyai aktivitas fisik sedang atau berat. Kejadian obesitas lebih tinggi jika responden mengalami stres sedang atau berat. Kejadian obesitas lebih tinggi pada kelompok usia di atas 30 tahun dibandingkan dengan kelompok usia di bawah 30 tahun. Tidak ada hubungan jenis kelamin, pendidikan, pengetahuan, sikap, dan konsumsi energi dengan obesitas. Kejadian obesitas cenderung lebih tinggi pada perempuan, berpendidikan tinggi, berpengetahuan baik, yang mempunyai pengetahuan negatif, tetapi hubungan tersebut secara statistik tidak bermakna. Kejadian obesitas hampir sama pada responden dengan konsumsi energi kurang atau cukup sehingga disimpulkan tidak ada hubungan antara konsumsi energi dengan kejadian obesitas (Tabel 2).

Model akhir analisis multivariat adalah variabel yang mempunyai nilai $\mathrm{p}$ lebih kecil dari 0,05 . Variabel yang berhubungan bermakna dengan obesitas adalah aktivitas fisik, stres, dan usia. Pada variabel aktivitas fisik dan stres dikategorikan menjadi ringan, sedang dan berat. Variabel usia dikategorikan menjadi 19-29 tahun, 30-49 tahun, dan 50-64 tahun. Pada mereka dengan tingkat stres dan aktivitas fisik yang sama, semakin berat aktivitas fisik, semakin kecil risiko obesitas. Subjek yang beraktivitas fisik sedang berisiko 0,4 kali lebih kecil untuk mengalami obesitas dibandingkan dengan yang beraktivitas fisik ringan. Subjek yang beraktivitas fisik berat berisiko 0,6 kali lebih kecil untuk mengalami obesitas daripada yang beraktivitas fisik ringan. Pada responden yang berusia dan aktivitas fisik yang sama, semakin berat tingkat stres, semakin besar risiko obesitas. Subjek yang mengalami stres sedang berisiko 4,6 kali lebih besar untuk mengalami obesitas daripada yang mengalami stres ringan. Subjek yang mengalami stres berat berisiko 2,4 kali lebih besar untuk mengalami obesitas dibandingkan dengan yang mengalami stres ringan. Pada yang mempunyai tingkat stres dan aktivitas fisik yang sama, semakin tua usia semakin besar risiko obesitas. Subjek dengan usia 30 - 49 tahun berisiko 2,3 kali lebih besar untuk mengalami obesitas daripada yang berusia kurang dari 30 tahun. Subjek dengan usia 50 - 64 tahun berisiko 2,5 kali lebih besar untuk mengalami obesitas dibandingkan dengan usia kurang dari 30 tahun (Tabel 3).

\section{Pembahasan}

Penelitian ini menggunakan jenis desain potong lintang sehingga hubungan kausalitas variabel aktivitas fisik dan stres harus diinterpretasikan dengan hati-hati. Mereka yang sudah obesitas dapat mengalami stres yang lebih tinggi dan kemudian lebih cenderung melakukan aktivitas fisik sehingga keeratan hubungan hasil penelitian ini mungkin lebih besar dari yang seharusnya (overestimate). Sampel penelitian ini hanya meliputi satu unit kerja Sekretariat Jenderal Kemenkes Republik Indonesia sehingga generalisasi untuk keseluruhan PNS Kemenkes RI harus dilakukan dengan hati-hati. Dengan asumsi bahwa pegawai pada Sekretariat Jenderal mempunyai tugas pokok dan fungsi yang tidak jauh berbeda dengan unit kerja lain, berarti sampel telah mewakili dan hasil penelitian ini dapat menggambarkan keseluruhan PNS Kemenkes RI.

Penelitian ini menggunakan kuesioner yang diisi sendiri oleh responden sebagai alat ukur untuk menge-

Tabel 1. Obesitas, Aktivitas Fisik, dan Stres pada PNS

\begin{tabular}{lll}
\hline Karakteristik & Kategori & $\%$ \\
\hline Obesitas & Tidak & 51,7 \\
\multirow{2}{*}{ Aktivitas fisik } & Ya & 48,3 \\
& Ringan $(<5,6)$ & 33,9 \\
Tingkat stres & Sedang $(5,6-7,9)$ & 36,5 \\
& Berat $(>7,9)$ & 29,6 \\
Jenis kelamin & Ringan $(17-20)$ & 6,5 \\
& Sedang $(21-27)$ & 33,5 \\
& Berat $(28-41)$ & 60,0 \\
& Laki-laki & 53,5 \\
\hline
\end{tabular}


Tabel 2. Analisis Sederhana Karakteristik Responden, Asupan Gizi, Aktivitas Fisik, dan Stres dengan Obesitas

\begin{tabular}{|c|c|c|c|c|c|}
\hline \multirow{2}{*}{ Variabel } & \multirow{2}{*}{ Kategori } & \multicolumn{2}{|c|}{ Obesitas } & \multirow{2}{*}{ Total } & \multirow{2}{*}{ Nilai $p$} \\
\hline & & Ya $(n=111)$ & Tidak $(n=119)$ & & \\
\hline \multirow[t]{3}{*}{ Aktivitas fisik } & Ringan & 57,7 & 42,3 & 78 & \\
\hline & Sedang & 38,1 & 61,9 & 84 & 0,013 \\
\hline & Berat & 50,0 & 50,0 & 68 & 0,353 \\
\hline \multirow[t]{3}{*}{ Tingkat stres } & Ringan & 26,7 & 73,3 & 15 & \\
\hline & Sedang & 40,3 & 59,7 & 77 & 0,004 \\
\hline & Berat & 60,8 & 39,1 & 138 & 0,017 \\
\hline \multirow[t]{3}{*}{ Usia (tahun) } & $19-29$ & 31,0 & 69,0 & 29 & \\
\hline & $30-49$ & 51,1 & 48,9 & 178 & 0,049 \\
\hline & $50-64$ & 47,8 & 52,2 & 23 & 0,219 \\
\hline \multirow[t]{2}{*}{ Jenis kelamin } & Perempuan & 51,4 & 48,6 & 107 & 0,449 \\
\hline & Laki-laki & 45,5 & 54,5 & 123 & \\
\hline \multirow[t]{2}{*}{ Pendidikan } & > Perguruan tinggi & 50,6 & 49,4 & 172 & 0,289 \\
\hline & $\leq \mathrm{SMA}$ & 41,4 & 58,6 & 58 & \\
\hline \multirow[t]{2}{*}{ Pengetahuan } & Baik & 51,0 & 49,0 & 51 & 0,778 \\
\hline & Kurang & 47,5 & 52,5 & 179 & \\
\hline \multirow[t]{2}{*}{ Sikap } & Positif & 44,9 & 55,1 & 118 & 0,363 \\
\hline & Negatif & 51,8 & 48,2 & 112 & \\
\hline \multirow[t]{2}{*}{ Konsumsi energi } & Cukup & 47,5 & 52,5 & 59 & 1,000 \\
\hline & Kurang & 48,5 & 51,5 & 171 & \\
\hline \multirow[t]{2}{*}{ Konsumsi karbohidrat } & Cukup & 53,4 & 46,6 & 58 & 0,446 \\
\hline & Kurang & 46,5 & 53,5 & 172 & \\
\hline \multirow[t]{2}{*}{ Konsumsi lemak } & Cukup & 47,4 & 52,6 & 57 & 0,998 \\
\hline & Kurang & 48,6 & 51,4 & 173 & \\
\hline \multirow[t]{2}{*}{ Konsumsi protein } & Cukup & 52,9 & 47,1 & 51 & 0,549 \\
\hline & Kurang & 46,9 & 53,1 & 179 & \\
\hline
\end{tabular}

Tabel 3. Model Regresi Logistik Ganda Pengaruh Aktivitas Fisik, Stres, dan Umur terhadap Obesitas

\begin{tabular}{llcllll}
\hline Variabel Prediktor & Kategori & B & Wald & Nilai $\mathbf{p}$ & OR & 95\% CI \\
\hline Aktivitas fisik & Ringan & - & 11,9 & 0,003 & & \\
& Sedang & $-0,815$ & 11,9 & 0,001 & 0,44 & $0,28-0,70$ \\
& Berat & $-0,406$ & 2,6 & 0,105 & 0,67 & $0,41-1,09$ \\
Stres & Ringan & - & 24,9 & 0,000 & & \\
& Sedang & 10,538 & 12,0 & 0,001 & 4,65 & $1,95-11,10$ \\
Usia (tahun) & Berat & 0,890 & 17,4 & 0,000 & 2,43 & $1,60-3,69$ \\
& $19-29$ & - & 22,9 & 0,025 & & \\
& $30-49$ & 0,835 & 6,9 & 0,008 & 2,30 & $1,24-4,28$ \\
& $50-64$ & 0,933 & 4,8 & 0,029 & 2,54 & $1,10-5,85$ \\
\hline
\end{tabular}

tahui asupan makanan, yang hanya berdasarkan pada ingatan responden sehingga memungkinkan terjadinya recall bias. Ada kecenderungan responden melaporkan lebih sedikit asupan makanan, sehingga zat gizi (energi, karbohidrat, protein, dan lemak) pada sebagian besar responden berada lebih rendah dari AKG dan hanya sedikit yang mencapai AKG sesuai indikator yang ditetapkan oleh Kemenkes. Metode food recall mempunyai kelemahan karena hanya mengandalkan ingatan responden. Akibatnya, dapat terjadi lupa, responden cenderung tidak melaporkan dengan benar makanan yang dimakan sehingga sering terjadi pengurangan informasi yang menyebabkan estimasi asupan energi menjadi lebih ren- dah dari yang seharusnya. ${ }^{13}$

Pada penelitian ini, obesitas ditentukan menggunakan cut off point dari WHO melalui pengukuran IMT. Seseorang dikatakan obesitas ketika nilai IMT $\geq 25$ $\mathrm{kg} / \mathrm{m}^{2}$. Hasil analisis didapatkan bahwa prevalensi obesitas PNS Sekretariat Jenderal Kementerian Kesehatan RI sekitar $48 \%$. Angka ini jauh lebih tinggi dibandingkan dengan prevalensi obesitas di Indonesia pada populasi umum. Pada Riskesdas tahun 2010, prevalensi obesitas di Indonesia 11,7\% dan di Jakarta 16,2\%.14 Aktivitas fisik yang ditemukan berhubungan bermakna dengan obesitas (nilai $\mathrm{p}=0,000$ ) adalah gerakan tubuh oleh otot rangka yang menghasilkan energi. Sementara, latihan 
(exercise) adalah aktivitas fisik yang direncanakan, terstruktur, dan dilakukan berulang-ulang dengan tujuan meningkatkan atau mempertahankan aspek kebugaran. Semakin berat aktivitas fisik semakin rendah kejadian obesitas. ${ }^{9-12,15}$

Bentuk tubuh orang dengan pekerjaan tidak banyak mengeluarkan energi berbeda dengan orang yang dengan pekerjaan selalu menggunakan otot atau banyak melakukan aktivitas fisik. Penggunaan energi bervariasi pada tingkat aktivitas fisik dan pekerjaan yang berbeda. Aktivitas fisik akan membakar energi dalam tubuh sehingga jika asupan kalori ke dalam tubuh berlebihan dan tidak diimbangi dengan aktivitas fisik yang seimbang akan menyebabkan tubuh mengalami kegemukan. ${ }^{16}$ Secara praktis dapat dikatakan bahwa aktivitas fisik yang kurang merupakan faktor risiko utama kegemukan dan obesitas, walaupun penelitian potong lintang hanya menemukan hubungan yang moderate antara tingkat aktivitas fisik dengan kegemukan dan obesitas, tetapi pada penelitian kohort longitudinal menyimpulkan hubungan yang kuat antara aktivitas fisik kurang dengan penambahan berat badan yang tinggi. ${ }^{12}$ Penelitian ini sedikit berbeda dengan penelitian sebelumnya yang tidak menemukan hubungan yang bermakna antara aktivitas fisik dengan kejadian obesitas dengan nilai $p=0,640$. Perbedaan hasil tersebut dapat disebabkan oleh perbedaan alat ukur yang digunakan dalam pengukuran aktivitas fisik atau perbedaan variasi aktivitas fisik antara PNS Kementerian Kesehatan dengan PNS Kementerian Koperasi dan Usaha Kecil. ${ }^{17}$

Pada penelitian ini, stres berhubungan bermakna dengan obesitas (nilai $p=0,003$ ). Stres dapat mendukung kejadian obesitas yang disebabkan oleh perilaku dan metabolisme. Penelitian di Kanada, menemukan hubungan yang signifikan antara obesitas dengan pekerjaan yang mempunyai tekanan atau stres tinggi. Hal tersebut merupakan hasil dari keadaan biologis dan perilaku individu yang mengalami stres kerja. Obesitas pekerja dapat disebabkan oleh tekanan pekerjaan yang tinggi dan mereka tidak dapat menahan pikiran yang dihasilkan dari stres kerja. Stres dapat mendukung obesitas yang disebabkan perilaku dan metabolisme dan merupakan dampak lingkungan psikososial yang merugikan. ${ }^{18}$

Semakin tua usia seseorang, kurang aktif bergerak menyebabkan massa otot dalam tubuh cenderung menurun dan kehilangan otot menyebabkan perlambatan tingkat pembakaran kalori dalam tubuh. Semakin bertambah usia dan dengan asupan kalori yang tetap, tubuh semakin sulit untuk membakar kalori yang masuk sehingga terjadi penumpukan energi didalam tubuh dan berdampak pada obesitas. Hasil analisis hubungan antara usia dengan obesitas pada penelitian ini didapatkan nilai $p$ sebesar 0,008 dan 0,029 , berarti terdapat hubungan yang bermakna antara usia dengan kejadian obesitas.
Penelitian sebelumnya membuktikan hubungan yang bermakna antara usia dengan kejadian gizi lebih atau obesitas. ${ }^{19,20}$ Ketika semakin tua dan kurang aktif bergerak, massa otot tubuh cenderung menurun yang menyebabkan perlambatan tingkat pembakaran kalori, sehingga tubuh semakin sulit membakar kalori yang masuk. Semakin lama, terjadi penumpukan energi didalam tubuh yang berdampak pada obesitas. Pria mempunyai tingkat metabolisme istirahat lebih tinggi daripada perempuan, sehingga pria membutuhkan lebih banyak kalori untuk menjaga berat badan mereka. ${ }^{21}$ Namun, dalam penelitian ini perbedaan ini tidak terbukti, uji statistik jenis kelamin dengan obesitas menemukan nilai $\mathrm{p}=0,449$. Tidak terdapat hubungan yang bermakna antara jenis kelamin dengan kejadian obesitas.

Pengetahuan tidak berhubungan bermakna dengan obesitas (nilai $p=0,363$ ), pengetahuan yang menyatakan proses belajar manusia mengenai kebenaran atau jalan yang benar untuk mengetahui yang harus diketahui untuk dilakukan, ternyata tidak terbukti pada penelitian tentang obesitas. Walaupun pegawai Kemenkes mempunyai pengetahuan yang baik tentang obesitas, mereka belum tentu berusaha mencegahnya karena pada kelompok tertentu sikap dengan perilaku tidak selalu berhubungan secara linier. 22,23 Sikap dengan obesitas tidak berhubungan bermakna dengan nilai $p=0,363$. Sikap seseorang dapat positif seperti setuju atau senang terhadap sesuatu dan dapat negatif yang tidak setuju, anti dan benci terhadap suatu objek. Pada penelitian ini, pegawai Kemenkes cenderung mempunyai sikap positif tentang obesitas dengan kejadian obesitas yang lebih rendah daripada yang mempunyai sikap negatif (44\% berbanding $51 \%$ ), tetapi perbedaan secara statistik tidak bermakna. Walaupun pegawai Kemenkes bersikap baik tentang obesitas, belum tentu mereka berusaha untuk mencegahnya karena pada kelompok tertentu sikap dengan perilaku tidak selalu berhubungan secara linier. ${ }^{22,23}$

Tidak terdapat hubungan yang bermakna antara konsumsi energi, karbohidrat, lemak, dan protein dengan kejadian obesitas. Penelitian sebelumnya juga menemukan hubungan yang bermakna antara konsumsi energi, konsumsi karbohidrat, konsumsi lemak, dan konsumsi proteindengan kejadian obesitas. ${ }^{14,20}$ Ada kecenderungan responden melaporkan lebih sedikit asupan makanan sehingga zat gizi (energi, karbohidrat, protein, dan lemak). Pada penelitian ini, hanya sedikit yang mencapai AKG yang ditetapkan oleh Depkes. Sebagian besar responden melaporkan konsumsi zat gizi dibawah AKG (lebih dari $75 \%)$. Homogenitas konsumsi zat ini kemungkinan menjadi penyebab tidak ada hubungan yang bermakna antara konsumsi gizi dengan obesitas pada PNS Setjen Kemenkes RI. Obesitas sudah muncul terlebih dahulu, kemudian responden memperbaiki pola konsumsi sehingga terjadi kerancuan dalam penentuan hubungan sebab akibat 
antara konsumsi zat gizi dengan obesitas. Hal tersebut merupakan salah satu kelemahan utama pada rancangan penelitian potong lintang.

\section{Kesimpulan}

Prevalensi obesitas pada PNS di Sekretariat Jenderal Kementerian Kesehatan RI Tahun 2013 adalah sebesar $48 \%$. Sebagian besar responden berusia $30-49$ tahun, berjenis kelamin laki-laki, berpendidikan tinggi, berasal dari suku bangsa Jawa, mempunyai pengetahuan kurang tentang obesitas, bersikap positif terhadap obesitas, kurang konsumsi energi, kurang konsumsi karbohidrat, kurang konsumsi lemak, kurang konsumsi protein, beraktivitas fisik sedang, dan mengalami stres berat. Hasil analisis multivariat regresi logistik memperlihatkan hubungan bermakna antara aktivitas fisik dan stres serta usia dengan kejadian obesitas. Semakin berat aktivitas fisik, semakin rendah risiko obesitas. Semakin berat stres semakin tinggi risiko obesitas, semakin tua usia semakin tinggi risiko obesitas. Tidak ada hubungan bermakna antara karakteristik individu dan konsumsi zat gizi makro dengan kejadian obesitas.

\section{Saran}

Pegawai Kemenkes RI yang mengalami obesitas disarankan untuk menurunkan berat badan dengan meningkatkan aktivitas fisik, mengurangi stres, dan memperhatikan asupan makanan sehari-hari. Kemenkes RI perlu memberikan informasi kepada seluruh pegawai dengan melakukan penyuluhan tentang gizi yang penting untuk menunjang aktivitas pegawai di tempat kerja oleh unit teknis terkait. Direktorat Gizi dan Kesehatan Ibu dan Anak, dan berkoordinasi dengan Pusat Promosi Kesehatan dan Pusat Kesehatan Kerja dan Olahraga. Penyuluhan sebaiknya berisi informasi tentang gizi seimbang, pemantauan berat badan, kebutuhan energi masing-masing individu, pengenalan zat gizi serta fungsinya, dan makanan-makanan yang baik untuk dikonsumsi serta risiko penyakit yang muncul jika seseorang mengalami obesitas. Jadwal olahraga rutin bersama yang telah ditetapkan setiap hari Jumat pagi dilaksanakan dengan baik. Memanfaatkan fasilitas olahraga (fitness center) untuk menurunkan kejadian obesitas. Melakukan kegiatan penyuluhan tentang gaya hidup sehat dan pencegahan stres, serta rutin melakukan gathering atau outbound yang dapat menurunkan kejadian stres.

\section{Daftar Pustaka}

1. World Health Organization. Obesity: preventing and managing global epidemic. Report of a WHO Consultation Technical Report Series 894. Geneva, Switzerland: WHO; 2010.

2. World Health Organization. Overweight and obesity [fact sheet on internet]. Departement of Sustainable Development and Healthy Environments. 2011 [cited 2013 Jul 4]. Available from: www.who.- int/medicare/factsheets/fs311/en/.

3. Lee YS, So JBY, Yap MD. Confronting the obesity epidemic: call to arms. Annals Academy of Medicine. 2009; 38 (1): 1-2.

4. Gibney MJ. Gizi kesehatan masyarakat. Jakarta: EGC; 2008.

5. Ogden CL, Carroll MD. Prevalence of overweight, obesity, and extreme obesity among adults: United States, Trends 1960 - 1962 through 2007 - 2008. Atlanta: National Center for Health Statistics; 2010.

6. Kementerian Kesehatan Republik Indonesia. Riset Kesehatan Dasar tahun 2007. Jakarta: Badan Penelitian dan Pengembangan Kesehatan, Kementerian Kesehatan; 2008.

7. Vassallo J. Pathogenesis of obesity. J Malta Coll Pharm Prac [serial on internet]. 2007 [cited 2012 Feb 13]; 12. Available from: www.meppnet.org/publications/ISSUE12-7.pdf.

8. Amber AWA, Heijden Vd, Hu FB, Rimm EB, Van Dam RM. A prospective study of breakfast consumption and weight gain among U.S. Men. Obesity. 2007; 15 (10): 2463-9.

9. Corti BG, Macintyre S, Clarkson JP, Pikora T, Donovan RJ. Environmental and lifestyle factors associated with overweight and obesity in Perth, Australia. American Journal of Health Promotion. 2003; 18(1).

10. Dietz W. The role of lifestyle in health: the epidemiology and consequences of inactivity. Proceeding of the Nutrition Society. 1996; 55: 829-40.

11. Prentice AM, Jebb S. Energy intake/physical activity interaction in the homeostasis of body weight regulation. Nutrition Review. 2004; 62: 98 104.

12. Dishman RK, Washburn RA, Health GW. Physical activity epidemiology. Champaign: Human Kinetics; 2004.

13. Gibson RS. Principles of nutritional assesment. New York: Oxford University Press; 2005.

14. Kementerian Kesehatan Republik Indonesia. Riset kesehatan dasar tahun 2010. Jakarta; Badan Penelitian dan Pengembangan Kesehatan, Kementerian Kesehatan; 2010.

15. Baecke JA. A short questionnaire for the measurement of habitual phsycal activity in epidemiological studies. Am J of Clin Nutrition [serial on internet. 1982 [cited 2013 Apr 4]; 36(5): 936-42. Available from: www.ncbi.nlm.nih.gov/pubmed/7137077.

16. Kantachuvessiri A, Sirivichayakul C, Kungwali JK, Tungtrongchitr R, Lotrakul M. Factors associated with obesity among workers in a metropolitan waterworks authority. Southeast Asian Journal of Tropical Medicine and Public Health. 2005; 36: 1057-65.

17. Bantarpraci S. Hubungan karakteristik individu, aktivitas fisik, asupan zat gizi makro (asupan energi, protein, lemak, dan karbohidrat) dengan obesitas di Kementerian Koperasi dan Usaha Kecil Menengah tahun 2012 [Skripsi]. Depok: Fakultas Kesehatan Masyarakat Universitas Indonesia; 2012.

18. Park J. Obesity on the job. Statistic Canada [article on internet]. 2009 [cited 2013 Jun 2]. Available from: www.statcan.gc.ca/pub/75-001x/2009102/article/10789_eng.htm.

19. Sudikno. Aplikasi regresi logistik pada hubungan aktivitas fisik dengan kejadian obesitas pada orang dewasa di Indonesia (analisis data Riskesdas 2007) [Tesis]. Depok: Fakultas Kesehatan Masyarakat Universitas Indonesia; 2010.

20. Christina D, Sartika RAD.Obesitas pada pekerja minyak dan gas. Kesmas Jurnal Kesehatan Masyarakat Nasional. 2011; 6(3): 104-10. 
21. Myers MD. Causes of obesity [online]. 2004 [cited 2013 Feb 13]. Diunduh dalam: http://www.weight.com/causes.asp.

22. Gordon L. Obesity related knowledge, attitude and behaviors in obese urban Philadelpia female adolescent. Obesity Research. 2002. 9: 112 118.
23. Kruger J. Behavioral risk factors associated with overweight and obesity among older adults: the 2005 national health interview survey. Prev Chron Dis [serial on internet]. 2009 [cited 2013 Feb 5]; 6 (1): A14. Available from: www.cdc.gov/pcd/issues/2009/join/07_0183.htm. 